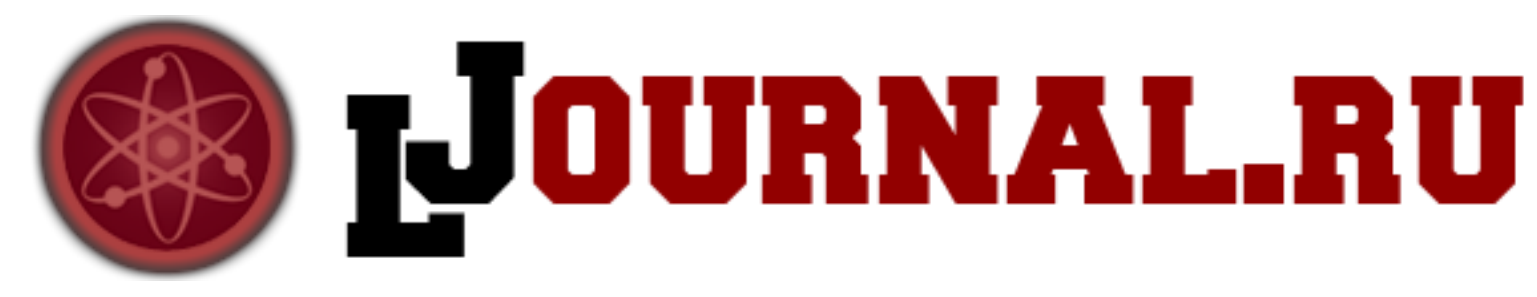

\author{
Воронин А.В. \\ ГБОУ ВПО СамГМУ Минздрава России \\ Самара, Россия
}

doi: 10.18411/1j2016-1-05

\title{
Методология фармацевтического и химико-токсикологического анализов
}

В настоящее время существует объективная необходимость определения понятий «фармацевтический анализ», «химико-токсикологический анализ», а также перечня требований к подготовке специалиста - химика-аналитика для вышеуказанных направлений.

В недостаточной мере обоснован методологический подход к процедуре разработки методик анализа для целей контроля качества лекарственных средств (химический анализ) и химико-токсикологического анализа (химикотоксикологической экспертизы). При контроле качества лекарственных средств особого внимания требует система разработки методик анализа сложных многокомпонентных объектов - лекарственных препаратов, содержащих несколько действующих веществ, лекарственного растительного сырья и препаратов на их основе[2].

Аналогичная проблема существует в химико-токсикологическом анализе: анализируемые объекты (органы, биологические жидкости) имеют сложный состав, набор сопутствующих (балластных) веществ сильно варьирует в пробах и существенный вклад в изменение содержания анализируемого вещества в объекте вносят распределение и метаболизм.

В химико-токсикологическом анализе применяемые методики анализа биологических объектов не являются аттестованными, соответственно для них 
отсутствует перечень аналитических и метрологических характеристик. В раздел Федерального реестра МВИ «Сведения об аттестованных методиках (методах) измерений. Биологические и биомедицинские измерения» (по состоянию на декабрь 2015 г.) включена только «Методика измерений массовой концентрации этанола в крови, моче и слюне» (МВИ №01.00225/205-42-12) [1].

Совершенно очевидно, что методика без регламентированных аналитических и метрологических характеристик не является доказательной и качество результатов анализа, полученных с помощью этой методики, невозможно оценить.

Необходима разработка методической базы метрологического обеспечения методик фармацевтического и химико-токсикологического анализов. Наличие вышеуказанной методической базы и четко определенных алгоритмов действия для практических работников в области фармацевтического и химико-токсикологического анализа обеспечит доказательность всей процедуры исследования и позволит проводить систематическую оценку качества результатов анализа.

Основой прикладной методологии фармацевтического анализа и химикотоксикологической экспертизы является система принципов и подходовдеятельности по разработке методик анализа.Кроме того, важным элементом является разработка практических рекомендаций по обеспечению качества исследований в вышеуказанных направлениях анализа.

Таким образом, формирование научно-практической обеспеченности исследований в фармацевтическом анализе и химико-токсикологической экспертизе принципами, формами и методами обеспечения качества и достоверности проводимых исследований невозможно без создания нового научного направления по методологическому обоснованию, разработке подходов к аттестации и оценке пригодности методов выполнения измерений, обоснованности применения разработанных методик анализа. 


\section{Литература:}

1. Малкова Т.Л. Методологическое обоснование обеспечения качества судебно-химических экспертных исследований лекарственных средств: автореф. дис. ... д. фарм. н.: 14.04.02, 14.04.03. - Пермь, 2012. - 43 с.

2. Руководство по инструментальным методам исследований при разработке и экспертизе качества лекарственных препаратов / Под ред. Быковского С.Н., Василенко И.А., Харченко М.И. [и др.]. - М., 2014. - 656 с. 